\title{
Testing Combined Effect of Amendments and Inoculation with Bacteria for Improving Phytostabilisation of Smelter Waste Extremely Contaminated with Trace Elements
}

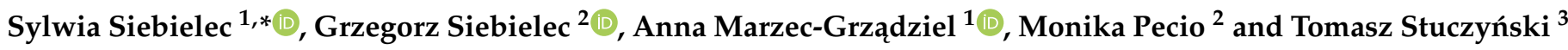 \\ 1 Department of Microbiology, Institute of Soil Science and Plant Cultivation-State Research Institute, \\ Czartoryskich 8, 24-100 Pulawy, Poland; agrzadziel@iung.pulawy.pl \\ 2 Department of Soil Science Erosion and Land Protection, Institute of Soil Science and Plant \\ Cultivation—State Research Institute, Czartoryskich 8, 24-100 Pulawy, Poland; gs@iung.pulawy.pl (G.S.); \\ mpecio@iung.pulawy.pl (M.P.) \\ 3 Faculty of Science and Health, The John Paul II Catholic University of Lublin, Konstantynów 1H, \\ 20-708 Lublin, Poland; Tomasz.Stuczynski@sgs.com \\ * Correspondence: ssiebielec@iung.pulawy.pl
}

Citation: Siebielec, S.; Siebielec, G.; Marzec-Grządziel, A.; Pecio, M.; Stuczyński, T. Testing Combined Effect of Amendments and Inoculation with Bacteria for Improving Phytostabilisation of Smelter Waste Extremely Contaminated with Trace Elements. Agronomy 2021, 11, 2064. https:// doi.org/10.3390/agronomy11102064

Academic Editors: Maria Pilar Bernal and Paula Alvarenga

Received: 16 September 2021

Accepted: 11 October 2021

Published: 14 October 2021

Publisher's Note: MDPI stays neutral with regard to jurisdictional claims in published maps and institutional affiliations.

Copyright: (c) 2021 by the authors. Licensee MDPI, Basel, Switzerland. This article is an open access article distributed under the terms and conditions of the Creative Commons Attribution (CC BY) license (https:/ / creativecommons.org/licenses/by/ $4.0 /)$.

\begin{abstract}
Smelter waste deposits pose environmental and health threats and require remediation actions. Phytostabilisation techniques, based on soil amendments, help to establish plant cover and limit the secondary emission of potentially toxic trace elements. However, methods to optimize their effectiveness are needed. The application of bacterial inoculants in combination with soil amendments in the remediation of soils and wastes contaminated with metals still has not been extensively tested. Therefore, the aim of this study was to determine the effectiveness of indigenous (Streptomyces sp., Pseudomonas sp.) and foreign (Streptomyces costaricanus) strains of bacteria in supporting grass growth on extremely contaminated waste slag. They were applied alone and in combination with compost mixed with phosphate fertilizer or iron oxide. The tested strains improved plant growth and increased plant availability of phosphorus. The interaction of the soil amendments and some bacterial strains also stimulated a decrease in the extractability of metals, likely through the phosphate-induced precipitation of lead. Our data show that the effectiveness of soil amendments in the phytostabilisation of heavily polluted smelter deposits can be enhanced by plant growth-promoting bacteria (PGPB).
\end{abstract}

Keywords: smelter waste; inoculation; soil amendments; metal solubility; microbial activity

\section{Introduction}

Smelter waste deposits pose an environmental and health threat worldwide. They are sources of secondary emissions of potentially toxic trace elements (TE), such as, for example, cadmium $(\mathrm{Cd})$, lead $(\mathrm{Pb})$, zinc $(\mathrm{Zn})$ and arsenic (As). Especially in populated areas, there is an urgent need to reduce the secondary spread of TE from barren deposits. One of potential strategies is to revegetate them and stabilize them by establishing a plant cover (phytostabilisation). Such approach reduces the wind and water erosion of a deposit, as well as the leaching of pollutants, resulting in limited secondary emissions of TE. Such a gentle approach is needed in cases where resources for the advanced engineering treatment of waste are not available or the recovery of metals is not justified. The traditional revegetation strategy of such waste piles has mainly been based on the intensive application of fertilizers, followed by various mixtures of grasses [1,2]. However, such approaches have been mostly ineffective over the long term. Also, in wider practice top-soiling, meant to cover waste with clean soil, is not used because high-quality soil material is unavailable [3].

Recent evaluations of long-term pilot sites have shown that the application of high rates of organic amendments (sewage sludge, compost) and lime supported quite effective revegetation of high-metal waste heaps, which further reduced the spread of pollu- 
tants [3-5]. Additionally, Siebielec et al. [5] documented the positive effect of sewage sludge and lime on the biodiversity and biological activity of such constructed soil layers. The stimulated microbial activity and greater abundance of certain groups of microorganisms improve the resistance of the entire constructed ecosystem to environmental stresses.

Despite the promising results of these pilot studies, the implementation of phytostabilization projects in post-industrial areas is still limited. This is partly due to the still-limited scientifically sound data demonstrating the short and long-term sustainability of smelterwaste remediation methods. Additionally, in many countries, the excessive use of organic materials (sewage sludge, compost) in the reclamation of severely polluted lands may be limited by the legal or financial circumstances. Therefore, there is a need for further research on the progress being made in remediation protocols, especially those aimed at the optimization of remediation effects and limiting the potential side-effects of excessive use of organic materials (cost, the release of nitrogen). Remediation methods enabling the reduction of sewage sludge or compost use without reducing remediation effectiveness would be, therefore, needed.

Recent studies have shown that complex interactions between plants and their microbiomes lead to the transformation of smelter waste into soil-like material, much better suited to plant growth [6]. Therefore, the application of selected bacterial strains appears to be an additional component of phytostabilisation technology, worthy of wider analysis. It can be assumed that the introduction of bacterial strains can further support and optimize the development and performance of plant cover on revegetated sites, resulting in more resistant revegetation over both the short and long terms. This can also theoretically contribute to the reduction of organic amendment rates, where high rates are not recommended for social, legal or organizational reasons. In such places, the use of plants and microbes would be preferred due to their cost effectiveness, environmental friendliness and the fewer side effects associated with them [7].

The application of bacterial inoculants is quite commonly used in the bioremediation of organic pollutants [8-12]. Siebielec et al. [12] documented that the application of previously selected strains of microorganisms can diminish the negative effects of contaminated bottom sediment with a range of metals and organic pollutants. The use of microorganisms in the phytoremediation of soils and wastes contaminated with metals still has not been extensively tested. So far, studies exploring the capacities of plant-derived bacteria to improve phytoremediation techniques are rather scarce $[11,13,14]$. It can be assumed that, in phytostabilisation systems, plant growth-promoting bacteria (PGPBs) can stimulate plant growth by producing phytohormones (such as indole acetic acid-IAA), inhibiting the stress production of ethylene (due to ACC deaminase activity), releasing essential nutrients (e.g., $\mathrm{N}_{2}$ fixers, phosphate solubilizers and siderophore producers) or inducing plant defense mechanisms [11]. It is worth mentioning that plants often suffer from water deficiency in the constructed ecosystems of revegetated waste piles, since they fully rely on precipitation for water. Vurukonda et al. [15], in their review, present the potential bacterial mechanisms of stimulating plant resistances to drought. The authors attribute such positive effects to PGPB phytohormonal activity, most often associated with the production of IAA, deaminase activity, the accumulation of proline, cytokinins and auxins, as well as the induction of genes responsible for plants' responses to drought conditions.

From both the scientific and practical point of view, whether indigenous bacteria isolated from waste will be more effective in supporting plant growth than foreign strains of bacteria is an interesting question. It can be assumed that indigenous bacteria would be well-adapted to the conditions found in a given site. Therefore, the aim of this greenhouse study was to determine the effectiveness of indigenous and foreign strains of bacteria, isolated from severely contaminated sites, applied alone or in combination with soil amendments, in supporting grass growth on a waste slag extremely contaminated with zinc, lead, cadmium and arsenic. 


\section{Materials and Methods}

\subsection{Smelter Waste Material}

Industrial mining and the smelting of metal ores have created hundreds of historically contaminated sites. In the Ślaskie Voivodeship, PL, heaps of zinc and lead slag are scattered within a mosaic of various types of land use, such as residential areas, arable land, forest and allotments. These deposits are generally barren due to extremely unfavorable plant growth conditions, created by the toxicity of metals (mainly Zn), harsh textures, very low water retention and a lack of nutrients. As a consequence, they remain a significant source of secondary emission of metals and of human exposure to toxic metals. The substrate for the study, which, for simplification, will be hereafter called soil, was collected from a barren area of such a slag dump site located in the area of a decommissioned smelter in Piekary Ślaskie (coordinates for the central point of the site: $50.364505 \mathrm{~N} ; 18.968960 \mathrm{E}$ ). The site has been widely characterized by Stuczynski et al. [3]. The waste deposit contains mainly waste slag from the Waeltz smelting process. The Zn oxide produced in this process, together with $\mathrm{Cd}$ and $\mathrm{Pb}$ compounds, becomes trapped in scrubbers, and the remaining waste is transported to the waste pile [3]. Thus, the waste is still very rich in $\mathrm{Zn}, \mathrm{Pb}$ and $\mathrm{Cd}$. The analysis of the portion of waste taken for the pot study revealed the following contents of $\mathrm{Zn}, \mathrm{Pb}, \mathrm{Cd}$ and As: 31,250; 20,750; 590 and $1560 \mathrm{mg} \mathrm{kg}^{-1}$ for $\mathrm{Zn}, \mathrm{Pb}, \mathrm{Cd}$ and As, respectively. The waste $\mathrm{pH}$ was neutral (7.8 as measured in $\mathrm{H}_{2} \mathrm{O}$ ). Organic matter content was $16 \%$. It was relatively high, however, as previously discussed by Siebielec et al. [5], OM, in this waste, apparently represents residual elemental carbon from the smelting process. Therefore, the found OM does not share the properties and functions of the soil organic matter found in agricultural soils.

\subsection{Bacterials Strains}

Three strains of rhizobacteria that had previously been isolated from contaminated soils were used as inoculants in the study. Streptomyces costaricanus RP92, representing a foreign strain, was isolated from Cytisus striatus rhizosphere growing in hexachlorocyclohexane$(\mathrm{HCH})$ contaminated soil and was characterized as a producer of IAA and siderophores [8]. Previously, the RP92 strain was shown to stimulate the growth of Lupinus luteus in dieselcontaminated soils, as well as to improve the decomposition of organic contaminants [16]. The strain has also shown a strong beneficial effect on the performance of Tagetes patula in soil enriched with heavily contaminated bottom sediments. The inoculation of the soil with the RP92 strain significantly improved the growth of plants and alleviated the chlorosis of their leaves [12].

Streptomyces sp. P9 (Gen Bank accession number MT658787) and Pseudomonas sp. P10 (Gen Bank accession number MT658788) were isolated from the same smelter slag pile from which the waste was collected for the pot study, but from the area of pilot remediation field, reclaimed in 1997 [5]. The strains were isolated from the transect treated with waste lime and sewage sludge. These strains exhibited phosphorus solubilization capabilities in laboratory plate tests by creating a transparent halo zone around the colony, grown on the substrate, rich in insoluble forms of phosphates.

Fresh cultures of bacterial strains (RP92, P9, P10) were grown in liquid media. The RP92 strain was grown in 869 liquid medium [17], as in a previous study [12], while strains P9 and P10 were grown in a medium suitable for bacteria exhibiting phosphorus solubilization [18]. Cultures were set up for $24 \mathrm{~h}$ and incubated at $28^{\circ} \mathrm{C}$ in a New Brunswick Scientific incubator (Excella E24 Incubator Shaker Series). Five millilitres of this pre-culture was then transferred to fresh liquid media, respective for a given strain, and incubated for $12 \mathrm{~h}$ at $28^{\circ} \mathrm{C}$. After this, the bacterial biomass was harvested by centrifugation $(6000 \mathrm{rpm}$, $15 \mathrm{~min}$ ), washed once with sterile $10 \mathrm{mM} \mathrm{MgSO}_{4}$ and re-suspended in $10 \mathrm{mM} \mathrm{MgSO}_{4}$ to an OD660 of 1.0 (about 107 cells per mL). 


\subsection{Experimental Setup}

The pot experiment was established in the growth chamber with fully controlled growth conditions (light, temperature). The 1-kg portions of homogenous smelter slag, sieved through a 2-mm mesh, were weighed and transferred into 1.5-L pots. We tested both individual bacteria's effects and the combined effects of bacteria and soil amendments. As two amendments to be tested, we selected the compost produced from sewage sludge and green waste, to which was added (a) Ca-phosphate, or (b) Fe-oxide. As previously documented, phosphates induce the precipitation of insoluble $\mathrm{Pb}$ compounds and likely reduce Zn solubility [19]. Iron oxides inactivate metals through adsorption or occlusion processes [20]. Compost has been proved as soil amendment effective in reducing plant available metals and improving plant growth in metal contaminated soils [21,22].

Phosphate was added to the soil as $\mathrm{CaHPO}_{4}$ reagent grade at a rate of $\mathrm{P}$ equal to $1 \%$ of soil. Fe oxides were added as $\mathrm{Fe}(\mathrm{OH})_{3}$ reagent grade as equivalent of $1 \%$ of soil. The compost originated from the process of pile composting of municipal sewage sludge and green waste as substrates in the facility in Pszczyna. It was added to the soil in the amount equivalent to $5 \%$ of soil (on a dry matter basis). It contained $29 \%$ of $\mathrm{OM}, 1.5 \% \mathrm{Fe}, 1.2 \% \mathrm{P}$, $2.3 \% \mathrm{Ca}$ and had $\mathrm{pH} 6.2$.

The experimental scheme is presented in Table 1.

Table 1. Experimental scheme of the greenhouse test.

\begin{tabular}{cccc}
\hline ID & \multicolumn{1}{c}{ Plant } & Amendment & Bacteria Strain \\
\hline L-0-0 & L. multiflorum & no amendment & no inoculation \\
L-0-P9 & L. multiflorum & no amendment & P9 \\
L-0-P10 & L. multiflorum & no amendment & P10 \\
L-0-RP92 & L. multiflorum & no amendment & RP92 inoculation \\
L-CPh-0 & L. multiflorum & compost plus Ca-phosphate & P9 \\
L-CPh-P9 & L. multiflorum & compost plus Ca-phosphate & P10 \\
L-CPh-P10 & L. multiflorum & compost plus Ca-phosphate & RP92 \\
L-CPh-RP92 & L. multiflorum & compost plus Ca-phosphate & no inoculation \\
L-CFe-0 & L. multiflorum & compost plus Fe oxide & P9 \\
L-CFe-P9 & L. multiflorum & compost plus Fe oxide & P10 \\
L-CFe-P10 & L. multiflorum & compost plus Fe oxide & RP92 \\
L-CFe-RP92 & L. multiflorum & compost plus Fe oxide & no inoculation \\
Ctrl & no plant & no amendment & \\
\hline
\end{tabular}

The pot test was run for 12 weeks in a greenhouse under additional light and temperature $25^{\circ} \mathrm{C} / 18{ }^{\circ} \mathrm{C}$ day/night with $16 / 8 \mathrm{~h}$ length of day/night, with three replications for each combination. The content of each pot (smelter waste and the amendments) was thoroughly mixed and homogenized in plastic bags and transferred back to the pots. The pots were left for 3 weeks in the growth chamber to let substrates and amendments react prior to the seeding with plants. The plant tested in the experiment was Italian ryegrass (Lolium multiflorum). The pots were watered with distilled water as needed.

Each pot was inoculated while the plants were germinating ( 3 weeks after sowing) with $100 \mathrm{~mL}$ of each bacterial suspension. The same amount of sterile $10-\mathrm{mM} \mathrm{MgSO}_{4}$ was added to the non-inoculated pots. Then inoculation was repeated after 3 weeks, using the same procedure.

After 12 weeks of growth, the plants were harvested, dried and weighed to determine shoots dry weights. After the harvest, the soil from each pot was mixed, sieved through a 2-mm mesh to remove plant debris, and soil aliquots were taken for further analysis. Each soil sample was divided into two portions: fresh soil samples were used for microbiological analyses, and air-dried samples were used to determine chemical parameters.

\subsection{Soil Analysis}

Microbial activity can create better growth conditions under stress through mobilizing nutrients or producing plant-growth promoters [23]. Therefore, in order to characterize 
the microbial activity of the soil, the intensity of three enzymes (dehydrogenases, acidic and alkaline phosphatases) were measured using standard protocols [24]. The determination of dehydrogenases was performed using the colorimetric method and according to Casida et al. [25], with TTC (triphenyltetrazolium chloride) as a substrate, after $24 \mathrm{~h}$ of incubation at $37^{\circ} \mathrm{C}$. Alkaline and acid phosphatase activities were measured by the colorimetric method using PNP (sodium p-nitrophenylphosphate) after $1 \mathrm{~h}$ of incubation at $37^{\circ} \mathrm{C}$ at $410 \mathrm{~nm}$ wavelength [26]. The color intensity of soil extracts was measured using the Thermo Fisher Scientific Evolution 60 UV-VIS spectrophotometer. Three replications of all biochemical measurements were performed.

The total count of cultivable bacteria [27], Azotobacter spp. [28], the total count of phosphorus solublizing bacteria (PSB) [18] and the count of cultivable fungi [29] were determined using the plate-dilution method. All biochemical and microbiological measurements were done in triplicate.

The soil $\mathrm{pH}$ was measured potentiometrically using a combined glass electrode in a slurry with a 1:2 v/v soil/DI water ratio. Organic matter (OM) content was measured by the loss on ignition in a muffle oven at $480{ }^{\circ} \mathrm{C}$, within $16 \mathrm{~h}$. Available phosphorus $(\mathrm{P})$ was measured using the Egner-Riehm colorimetric method after extraction with calcium lactate $(0.02 \mathrm{M})$ in diluted $\mathrm{HCl}(0.01 \mathrm{M})$, followed by measurement in a Perkin Elmer Lambda 45 Spectrometer, based on the color reaction with ammonium molybdate. Available potassium (K) was measured after the same extraction with calcium lactate by AAS, using AAnalyst 800 (Perkin Elmer, Waltham, MA, USA). Mineral nitrogen (N) extractability in $1 \mathrm{M} \mathrm{K}_{2} \mathrm{SO}_{4}$ was measured by flow spectrometry using QuAAtro39 analyser (Seal Analytical, Norderstedt, Germany).

Total trace element contents were measured after digestion of a sample in a 3:1 mixture of concentrated $\mathrm{HNO}_{3}: \mathrm{HCl}$ in Teflon PFA vessels in a microwave-accelerated reaction system (MarsXpress; CEM Corp., Matthews, NC, USA) followed by measurements of the elements in the extracts by ICP-MS (Agilent 7500ce). The analysis of metals' solubility was done by their extraction in $1 \mathrm{M} \mathrm{NH}_{4} \mathrm{NO}_{3}$ (1:2.5 soil/solution ratio, shaken for $2 \mathrm{~h}$ at room temperature) and a subsequent measurement of metal concentrations by ICP-MS. Certified reference materials (CRM) and internal laboratory standards were analyzed for the control of the chemical determinations. A CRM020-050 (RTC, WY) was used for the control of the total metal content analysis.

\subsection{Statistical Analysis}

In order to compare the effectiveness of the treatments, the results were expressed as means and the differences were considered significant at $p<0.05$. The results were subjected to analysis of variance (ANOVA) using the software Statistica v. 13.0 (TIBCO Software Inc., Palo Alto, CA, USA). The significance of difference was identified using Tukey's test.

\section{Results and Discussion}

\subsection{Microbiological and Biochemical Indices}

The enzymatic activities, which can be expressed by dehydrogenases or acid and alkaline phosphatase rates, are major biochemical indicators used to describe the biological quality of soils. Extracellular soil enzymes are synthesized and secreted by soil microorganisms and take part in the formation and decomposition of organic material [30]. Soil enzymes are mainly hydrolases that help to obtain carbon, nitrogen and phosphorus to support primary metabolism; or are oxidoreductases that contribute to the breakdown of organic compounds [31]. Dehydrogenases classified as oxidoreductases take part and accelerate the dehydrogenation reactions of specific substrates in the processes of biochemical oxidation of organic components. They occur in all living cells of microorganisms, therefore they are often considered indicators of the overall microbial activities of soils [32,33]. Phosphatases are responsible for the hydrolysis of organic phosphorus compounds and are 
indicators of the potential rate of their mineralization in the soil environment. Phosphatases are produced by microorganisms in response to low levels of inorganic phosphate [34].

Table 2 shows the enzymatic activities in soil samples collected after harvest. In general, the highest dehydrogenases activity was found in the combination where compost and phosphate were applied to the soil. This proved the stimulating effect of the compost amendment on microbial activity and in the alleviation of chemical stress to microorganisms related to heavy contamination. The highest activity was recorded for the L-CPh-0 treatment. The inoculation did not significantly increase the activity of dehydrogenases, regardless of the soil amendments.

Table 2. Enzyme activity of soil as dependent on the remediation treatment.

\begin{tabular}{|c|c|c|c|}
\hline ID & $\begin{array}{c}\text { Dehydrogenases } \\
\mu \mathrm{g} \text { TPF g Soil DM } \\
\mathrm{h}^{-1}\end{array}$ & 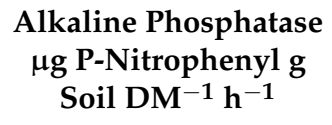 & $\begin{array}{c}\text { Acidic Phosphatase } \\
\mu \mathrm{g} \text { P-Nitrophenyl g } \\
\text { Soil DM }{ }^{-1} \mathrm{~h}^{-1}\end{array}$ \\
\hline L-0-0 & $1.03^{\mathrm{a} 1}$ & $12.89 \mathrm{bc}$ & $20.86^{b c}$ \\
\hline L-0-P9 & $0.91^{\mathrm{a}}$ & $13.22^{b c}$ & $18.48^{a b}$ \\
\hline L-0-P10 & $0.96^{\mathrm{a}}$ & $13.53^{b c}$ & $17.01^{\mathrm{a}}$ \\
\hline L-0-RP92 & $1.08^{a}$ & $12.65^{b}$ & $16.73^{\mathrm{a}}$ \\
\hline L-CPh-0 & $4.76^{\mathrm{d}}$ & $12.88^{b c}$ & $21.81^{\text {cde }}$ \\
\hline L-CPh-P9 & $3.60 \mathrm{~cd}$ & $14.09 \mathrm{bcd}$ & $22.61 \mathrm{bcd}$ \\
\hline L-CPh-P10 & $3.40^{\mathrm{cd}}$ & $16.57^{\mathrm{e}}$ & $24.27^{\text {cde }}$ \\
\hline L-CPh-RP92 & $3.87 \mathrm{~cd}$ & $15.89 \mathrm{de}$ & 24.91 de \\
\hline $\mathrm{L}-\mathrm{CFe}-0$ & $3.23 \mathrm{bc}$ & 14.90 cde & $24.91^{\mathrm{e}}$ \\
\hline L-CFe-P9 & $3.31^{\mathrm{bcd}}$ & $13.92^{\mathrm{bcd}}$ & $24.49 \mathrm{de}$ \\
\hline L-CFe-P10 & $3.07 \mathrm{bc}$ & $14.61^{\text {bcde }}$ & $22.28^{\text {cde }}$ \\
\hline L-CFe-RP92 & $1.80^{a b}$ & $13.29 \mathrm{bc}$ & 24.38 de \\
\hline Ctrl & $0.49^{a}$ & $10.18^{a}$ & $16.11^{\mathrm{a}}$ \\
\hline
\end{tabular}

${ }^{1}$ Means marked with the same letter did not differ significantly across the stress level within soil $(p<0.05, n=3)$ according to the Tukey test.

A lower diversity was observed for the alkaline phosphatase response. However, in general, compost added to the soil with phosphates stimulated alkaline phosphatase the most. In soils treated with compost and phosphates, a positive effect of inoculation was observed. Inoculation with the P10 and RP92 strains resulted in statistically greater activity than in L-CPh-0. Similarly, acidic phosphatase was stimulated by adding compost to the soil, which was similar for compost-phosphate- and compost-iron oxide-amended soils, regardless of the inoculation variants. Even in non-amended soils, the presence of plants increased the activity of both alkaline and acidic phosphatases. This emphasized the role of plant cover in initiating biological processes in such extremely contaminated soils.

The total number of cultivable bacteria in the soil is presented in Table 3. The greatest abundances of bacteria were recorded for the L-0-P10 and L-CFe-P9 treatments. There was some variability in the total count of bacteria and the results were rather inconsistent across soil-amendment types. However, all soil amendments combined with the inoculation increased the abundance of bacteria. Even the soil without amendments but inhabited by plants had bacteria in much more abundance than the control without plants. Plantmicrobial interactions result in a higher population density of microorganisms, even under stressful conditions such as soil metal contamination [6]. These interactions lead to heavy metal tolerance, as well as the stimulation of normal plant growth and development $[9,35]$.

Interestingly, in many cases the number of bacteria in the soil without amendments ( $\mathrm{L}-0$ combinations) was greater than in the compost-treated soils, but these bacteria were apparently much less active than in the amended soils, as documented by their enzyme activities (Table 2). Fungi constituted a larger share of the total community of cultivable microorganisms in Ctrl than in the amended or inoculated soils. The combinations which most stimulated fungi were L-CFe-0 and LCFe-P9 (Table 3). 
Table 3. Count of cultivable microorganisms, dependent on the remediation treatment used.

\begin{tabular}{|c|c|c|c|c|}
\hline ID & $\begin{array}{c}\text { Total Count of } \\
\text { Bacteria } \\
10^{7} \mathrm{CFU}_{\mathrm{g} \text { Soil }} \\
\mathrm{DM}^{-1}\end{array}$ & $\begin{array}{c}\text { Count of } \\
\text { Azotobacter } \\
10^{1} \text { CFU g Soil } \\
\text { DM }^{-1}\end{array}$ & $\begin{array}{c}\text { Count of PSB } \\
10^{7} \text { CFU g Soil } \\
\text { DM }^{-1}\end{array}$ & $\begin{array}{c}\text { Total Count of } \\
\text { Fungi } \\
10^{4} \mathrm{CFU} \mathrm{g} \text { Soil }^{\mathrm{DM}^{-1}}\end{array}$ \\
\hline L-0-0 & $120^{\mathrm{ab} 1}$ & $0^{c}$ & $5.3^{b c}$ & $6.0^{\mathrm{d}}$ \\
\hline L-0-P9 & $138^{\mathrm{ab}}$ & $0^{\mathrm{c}}$ & $1.7^{\mathrm{cd}}$ & $69.7^{b c}$ \\
\hline L-0-P10 & $260^{a}$ & $0^{\mathrm{c}}$ & $1.3^{\mathrm{cd}}$ & $84.0^{b c}$ \\
\hline L-0-RP92 & $115^{a b}$ & $0^{c}$ & $0.3^{\mathrm{cd}}$ & $15.0 \mathrm{~cd}$ \\
\hline $\mathrm{L}-\mathrm{CPh}-0$ & $125^{a b}$ & $9.7^{a b}$ & $4.7^{b c}$ & $13.3^{\mathrm{cd}}$ \\
\hline L-CPh-P9 & $116^{\mathrm{ab}}$ & $10.0^{\mathrm{ab}}$ & $22.0^{a}$ & $56.0^{\mathrm{bcd}}$ \\
\hline L-CPh-P10 & $74^{\mathrm{bc}}$ & $5.0^{\mathrm{ab}}$ & $10.0^{b}$ & $16.0^{\mathrm{cd}}$ \\
\hline L-CPh-RP92 & $61^{b c}$ & $5.0^{\mathrm{ab}}$ & $0.3^{\mathrm{cd}}$ & $19.3^{\mathrm{cd}}$ \\
\hline L-CFe-0 & $39^{c}$ & $15.7^{\mathrm{a}}$ & $3.7 \mathrm{bcd}$ & $156.0^{\mathrm{a}}$ \\
\hline L-CFe-P9 & $193^{a}$ & $13.0^{\mathrm{ab}}$ & $9.3^{b}$ & $108.0^{\mathrm{ab}}$ \\
\hline L-CFe-P10 & $97^{a b}$ & $8.7^{a b}$ & $8.3^{b}$ & $34.3^{\mathrm{cd}}$ \\
\hline L-CFe-RP92 & $77^{b c}$ & $8.0^{a b}$ & $9.3^{b}$ & $49.7 \mathrm{bcd}$ \\
\hline Ctrl & $11^{\mathrm{d}}$ & $0^{c}$ & $0^{d}$ & $82.7^{b c}$ \\
\hline
\end{tabular}

${ }^{1}$ Means marked with the same letter did not differ significantly across the stress level within soil $(p<0.05, n=3)$ according to the Tukey test.

The aerobic bacteria of the genus Azotobacter represent a diverse group of free-living diazotrophs commonly found in soil. These bacteria are extremely important for soil ecosystem due to their ability to fix atmospheric nitrogen and make it available for plants. Azotobacter is also known as a producer of a range of compounds that stimulate plant growth and development [36,37]. In our study we did not detect Azotobacter bacteria in the non-amended soils (Table 3). Compost apparently introduced Azotobacter to the soils and created conditions suitable for its growth. The results are in agreement with the observations of Siebielec et al. [5] in their field experiment conducted on the smelter waste heap in Piekary, Poland, where Azotobacter was not present in control plots. In our study, soil inoculation with P10 and RP92 strains slightly reduced the count of Azotobacter as compared with non-inoculated compost-treated soils. For P9 such a competition effect was not observed.

The ability of PSB to release phosphorus in the soil is variable, depending primarily on the mechanism used and genetics [38]. Additionally, PSBs have valuable features, such as the production of phytohormones regulating plant growth, binding atmospheric nitrogen and eliminating plant stress resulting from the presence of heavy metals in the soil [35,38-40]. PSBs are present throughout most soils, however, their number depends on soil properties, climatic conditions and plant cultivation [41,42]. PSBs have also been isolated from heavily contaminated soils $[5,16,43]$. In our study, PSBs were most numerous in the soil treated with the combination of compost and phosphates inoculated with the P9 strain. In general, compost stimulated teh abundance of PSB. No colonies were found in the control without plants (Table 3).

\subsection{Soil Chemical Parameters and Metal Extractability}

The initial $\mathrm{pH}$ of the smelter slag was slightly alkaline (pH 8.0) (Table 4). Compost amendment resulted in a small drop in $\mathrm{pH}(0.2-0.23$ unit), which had been previously observed in alkaline soils treated with significant amounts of organic materials [5,44]. This can be apparently attributed to the mineralization of high amounts of exogenous organic matter, accompanied by release of organic acids and sulphur.

Phosphorus (P) extractability was very low in the Ctrl and L-0 combinations. These were clearly deficit contents - the average available $\mathrm{P}$ in arable soils in Poland is almost 10 times greater $\left(167 \mathrm{mg} \mathrm{P}_{2} \mathrm{O}_{5} \mathrm{~kg}^{-1}\right)$ than was observed [45]. Compost alone greatly increased the phyto-availability of $\mathrm{P}$, apparently due to substantial amounts of phosphorus brought to the soil with the compost (Table 4). These levels were still rather low for 
intensively growing grass. Municipal sludges and sludge-based composts, in general, contain large amounts of phosphorus [46]. It has been also observed that the availability of $\mathrm{P}$ introduced to the soil with organic materials usually increased over time as a result of organic P's mineralization [47]. As expected, Ca-phosphate, added to the soil along with the compost, resulted in the high extractability of $\mathrm{P}$. In such treatments, $\mathrm{P}$ is added to the soil not only to provide $\mathrm{P}$ for plants, but also to deliver an excess of this element to enable the inactivation of $\mathrm{Pb}$ via the precipitation of highly insoluble $\mathrm{Pb}$ phosphates, which has been previously observed [19]. The P9 and the especially P10 and RP92 strains, introduced together with the compost-phosphate amendment, further increased P availability (statistically significant when the significance was calculated separately across L-CPh combinations). This fact suggests the capacity of the tested strains to solubilize inorganic $P$. Therefore, they apparently have high potential in optimizing the aided phytostabilisation of heavily contaminated soils and wastelands thanks to their capacity for releasing nutrients to plants and to stimulate the inactivation of $\mathrm{Pb}$. Phosphates in soil can greatly reduce $\mathrm{Pb}$ bioavailability, as documented in military-use-contaminated soils [22].

Table 4. Soil parameters as dependent on the remediation treatment.

\begin{tabular}{|c|c|c|c|c|}
\hline ID & $\begin{array}{c}\text { Soil } \mathrm{pH} \\
\mathrm{pH} \text { in } \mathrm{H}_{2} \mathrm{O}\end{array}$ & $\begin{array}{c}\text { Available } \\
\text { Phosphorus } \\
\mathrm{mg} \mathrm{P}_{2} \mathrm{O}_{5} \mathrm{~kg}^{-1}\end{array}$ & $\begin{array}{c}\text { Available } \\
\text { Potassium } \\
\mathrm{mg} \mathrm{K}_{2} \mathrm{O} \mathrm{kg}^{-1}\end{array}$ & $\begin{array}{c}\text { Extractable } \\
\text { Nitrates } \\
\mathrm{mg} \mathrm{N}^{\mathrm{N}} \mathrm{NO}_{3} \mathrm{~kg}^{-1}\end{array}$ \\
\hline L-0-0 & $7.97^{a 1}$ & $12.0^{\mathrm{C}}$ & $155.9^{b}$ & $1.4^{\mathrm{d}}$ \\
\hline L-0-P9 & $7.90 \mathrm{abc}$ & $12.0^{\mathrm{C}}$ & $143.7^{b c}$ & $1.0^{\mathrm{d}}$ \\
\hline L-0-P10 & $7.93^{a b}$ & $14.2^{\mathrm{C}}$ & $125.8^{b c d}$ & $0.8^{\mathrm{d}}$ \\
\hline L-0-RP92 & $7.93^{a b}$ & $9.6^{c}$ & $152.2^{b}$ & $0.6^{\mathrm{d}}$ \\
\hline $\mathrm{L}-\mathrm{CPh}-0$ & $7.77^{\mathrm{c}}$ & $470.1^{\mathrm{ab}}$ & $108.1^{\text {cde }}$ & $8.9 \mathrm{bcd}$ \\
\hline L-CPh-P9 & $7.80^{b c}$ & $590.8^{a}$ & $108.2^{\text {cde }}$ & $18.34^{\mathrm{abc}}$ \\
\hline L-CPh-P10 & $7.80 \mathrm{bc}$ & $864.0^{\mathrm{a}}$ & $109.8^{\text {cde }}$ & $27.21^{\mathrm{a}}$ \\
\hline L-CPh-RP92 & $7.80^{b c}$ & $762.1^{a}$ & $117.7^{\text {bcde }}$ & $10.08^{b c d}$ \\
\hline L-CFe-0 & $7.77^{\mathrm{c}}$ & $70.3^{c}$ & $110.8^{\text {cde }}$ & $21.33^{a b}$ \\
\hline L-CFe-P9 & $7.80^{b c}$ & $70.2^{c}$ & 90.2 de & $8.32^{b c d}$ \\
\hline L-CFe-P10 & $7.80^{b c}$ & $76.1^{b c}$ & $83.7^{\mathrm{e}}$ & $5.30^{\mathrm{cd}}$ \\
\hline L-CFe-RP92 & $7.80^{b c}$ & $77.9^{b c}$ & $98.1^{\text {de }}$ & $12.24^{\mathrm{bcd}}$ \\
\hline Ctrl & $8.00^{\mathrm{a}}$ & $18.0^{\mathrm{C}}$ & $206.1^{a}$ & $12.53^{b c d}$ \\
\hline
\end{tabular}

${ }^{1}$ Means marked with the same letter did not differ significantly across the stress level within soil $(p<0.05, n=3)$ according to the Tukey test.

Potassium (K) extractability simulates its availability to plants. It was sufficient in untreated soil (Ctrl) and was slightly reduced after harvest in all planted pots, likely due to $\mathrm{K}$ uptake by plants. It seems also that the addition of Fe oxides, which tend to convert into amorphous forms over time, further lowered $\mathrm{K}$ availability through occlusion of $\mathrm{K}$ ions (Table 4).

Smelter waste is very low in nitrogen, which is a deficit nutrient therein. Plantavailable forms of $\mathrm{N}$ are very low and therefore they have to be provided in phytostabilisation systems with soil amendments or with fertilizers. Nitrates in Ctrl were slightly greater than their levels measured in a study with smelter waste collected from the same waste deposit [6]. Nitrates were almost fully acquired by plants in soils where compost was not added (L-0 combinations). The scarce levels of $\mathrm{N}^{-\mathrm{NO}_{3}}$ in these pots also indicate that the nitrification process might have been strongly hampered due to metal toxicity. Nitrates were much more plentiful in compost-treated soils, where they originated from the transformation of organic $\mathrm{N}$ and more active nitrification (Table 4). The P10 strain increased nitrate availability in the compost- and phosphate-amended soils, as compared with L-CPh-0. This might indicate the role of P10 in the nitrogen cycling after bringing exogenous organic nitrogen to the soil.

Chemical extractions are used to simulate metal bioavailability in contaminated soils or test the effects of soil treatments on metal availability to various biological receptors. 
These methods are based on assumption that TE bioavailability correlates to its solubility/extractability. TE extraction using $1 \mathrm{M} \mathrm{NH}_{4} \mathrm{NO}_{3}$ has been proved effective in the prediction of TE's availability across sites subjected to gentle remediation strategies [48]. It has also become the standardized protocol for the evaluation of contaminated soils in Germany [49]. In our study, Cd extractability, in some cases, was significantly reduced after compost addition, despite a slight drop of $\mathrm{pH}$, as compared with Ctrl (Table 5). Such effect was even more pronounced for Zn extractability. It is worth noting that compost combined with Ca-phosphate significantly reduced Zn extractability more often than the compost-Fe oxide amendment. The results also indicate that the tested bacterial strains might have modified metals' availability - this was observed, especially, for P10, which reduced the extractability of $\mathrm{Cd}, \mathrm{Zn}$ and $\mathrm{Pb}$. The mechanism of this phenomena remains unclear. One of the potential explanations for this immobilising effect of bacterial strains might be the biosorption of metals by the introduced bacteria [50]. The P10 strain reduced $\mathrm{Pb}$ availability in soils treated with Ca-phosphates, which confirms its effectiveness in solubilizing $\mathrm{P}$ that subsequently precipitates $\mathrm{Pb}$ ions already present in the soil solution.

Table 5. Metals extractable in $1 \mathrm{M} \mathrm{NH}_{4} \mathrm{NO}_{3}$ as dependent on the remediation treatment.

\begin{tabular}{|c|c|c|c|}
\hline ID & $\begin{array}{c}\text { Cadmium } \\
\mathrm{mg} \mathrm{kg}^{-1}\end{array}$ & $\begin{array}{c}\text { Zinc } \\
\mathrm{mg} \mathrm{kg}^{-1}\end{array}$ & $\begin{array}{c}\text { Lead } \\
\mathrm{mg} \mathrm{kg}^{-1}\end{array}$ \\
\hline L-0-0 & $0.31^{a b c 1}$ & $3.30^{b c}$ & $0.73^{a b c}$ \\
\hline L-0-P9 & $0.30 \mathrm{abc}$ & $2.93 \mathrm{bc}$ & $0.73^{a b c}$ \\
\hline L-0-P10 & $0.26^{b c}$ & $2.86^{b c}$ & $0.71^{a b c}$ \\
\hline L-0-RP92 & $0.20^{a b c}$ & $2.64^{b c}$ & $0.59^{a b c}$ \\
\hline $\mathrm{L}-\mathrm{CPh}-0$ & $0.42^{\mathrm{ab}}$ & $3.38^{a b c}$ & $0.92^{\mathrm{a}}$ \\
\hline L-CPh-P9 & $0.34^{a b c}$ & $2.54^{\mathrm{c}}$ & $0.68^{a b c}$ \\
\hline L-CPh-P10 & $0.28 \mathrm{bc}$ & $2.79 \mathrm{bc}$ & $0.46^{\mathrm{c}}$ \\
\hline L-CPh-RP92 & $0.35^{a b c}$ & $3.09 \mathrm{bc}$ & $0.74^{\mathrm{abc}}$ \\
\hline L-CFe-0 & $0.44^{\mathrm{ab}}$ & $3.84^{\mathrm{ab}}$ & $0.80^{\mathrm{ab}}$ \\
\hline L-CFe-P9 & $0.37^{a b c}$ & $3.05^{b c}$ & $0.58^{b c}$ \\
\hline L-CFe-P10 & $0.38^{a b c}$ & $3.35^{a b c}$ & $0.66^{a b c}$ \\
\hline L-CFe-RP92 & $0.37^{a b c}$ & $3.51^{\mathrm{abc}}$ & $0.74^{\mathrm{abc}}$ \\
\hline Ctrl & $0.49^{\mathrm{a}}$ & $4.51^{\mathrm{a}}$ & $0.84^{\mathrm{ab}}$ \\
\hline
\end{tabular}

${ }^{1}$ Means marked with the same letter did not differ significantly across the stress level within soil $(p<0.05, n=3)$ according to the Tukey test.

\subsection{Plant Growth}

Italian ryegrass was severely stunted in the soil not treated with compost and plants' leaves were clearly chlorotic. This was the combined effect of metal toxicity, most likely Zn-induced Fe deficiency, and the deficiency of such nutrients as N and P. Plants growing on soil treated with compost and phosphate or Fe oxide looked healthy and did not exhibit any toxicity symptoms. Figure 1 shows the yield of the harvested biomass. The compost variants enabled much greater biomass production, whereas, without-soil-amendments yields were very small and it is evident that, over the long-term, plant cover would not survive on unamended smelter waste. Our data confirm previous reports on the effectiveness of sludge-based composts in establishing plant cover in extremely metalcontaminated soils $[21,22,51]$. As we confirmed in our study, it similarly supports plant growth in the smelter slag waste.

In non-inoculated variants, both compost with phosphate and compost with iron oxides enabled high yields of grass biomass, however slightly greater yield was produced in the soil treated with compost and Ca-phosphate (Figure 1a). It is possible that it was related to lower plant-availability of phosphorus in Fe-oxide-compost treated soil. 


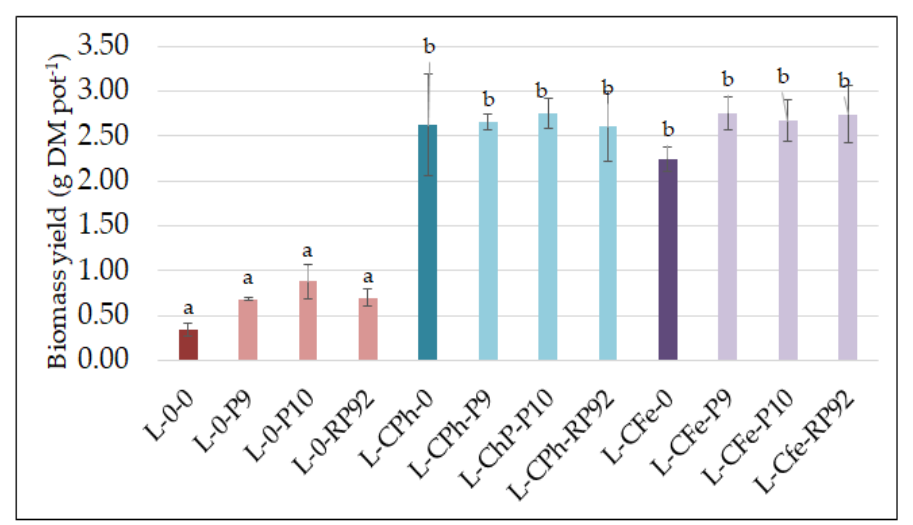

(a)

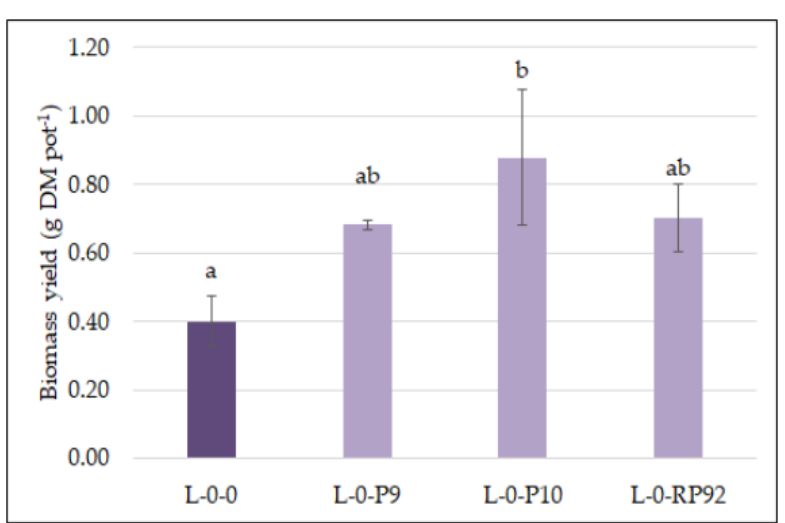

(b)

Figure 1. The effect of soil amendment and inoculation on grass biomass at harvest: (a) all treatments presented and statistically evaluated; (b) the effect presented and statistically evaluated separately for L-0 combinations (inoculation effect without soil amendments).

No statistically significant differences between the inoculated and non-inoculated variants were observed when all combinations were subjected to statistical analysis. However, when calculated separately for each combination of amendments, it became evident that inoculation significantly improved plant biomass in the soil without amendments and in the soil amended with compost and Fe-oxide. In case of the non-amended soil, the P10 strain was most effective in supporting the growth of the ryegrass (Figure 1b). In L-CFe soils, all tested strains further improved the yield of plant biomass. The potential mechanisms of enhancing plant growth by bacteria might include the production of phytohormones, such as indole acetic acid (IAA), suppressing stress ethylene production due to 1-aminocyclopropane-1-carboxylic acid (ACC) deaminase activity, the production of siderophores involved in the acquisition of $\mathrm{Fe}$, or solubilisation of inorganic phosphate [13]. The latter was likely one of key mechanisms in case of L-0 and L-CFe soils, both variants were characterized by a deficiency of plant-available phosphorus. As documented by Siebielec et al. [6], the interaction of plants and rhizosphere bacteria strongly improves the phytoavailability of nutrients for plants spontaneously inhabiting smelter wastelands. Therefore, improving the nutritional status of plants is definitely one of major mechanisms in supporting plant growth by bacteria in extremely metal-contaminated soils and wastes.

Some authors found a reduced uptake of metals by plants, resulting from application of rhizosphere bacterial inoculants [52]. Wang et al. [53] observed reduced $\mathrm{Cd}$ uptake by rice (Oryza sativa) and Cd bioavailability in soil inoculated with Cd-tolerant Pseudomonas TCd-1. The reduced metal uptake might obviously improve plant growth in the remediation systems dedicated to metal-rich soils.

However, very few studies have assessed the potential benefits of bacteria in an assisted phytostabilisation process that combines cultivating metal-excluding plants, metaltolerant PGPBs and metal-immobilizing soil amendments. PGPBs have been more often tested in metal phytoextraction systems [54,55]. Our data shows that the effectiveness of soil amendments in the phytostabilisation of heavily polluted smelter deposits can be enhanced by PGPB.

Potential bacterial inoculants might apparently originate from various taxa. In our study both Streptomyces sp. and the Pseudomonas sp. strain exhibited potentials to enhance the effect of soil amendments. The assumed advantage of indigenous strains over foreign bacteria has not been fully proven. This might mean that PGPBs can be effective in stimulating phytostabilisation process even if they are not of local origin, but must exhibit tolerance to heavy contamination. Therefore, smelter waste deposits remain potential sources of PGPB strains to be used in assisted phytostabilisation. 
Both Streptomyces sp. and Pseudomonas sp. have been classified as potentially useful inoculants by other authors. Streptomyces sp. has been classified as genus potentially effective in the phytoremediation processes, by Zappelini et al. [56]. The authors characterized bacterial communities in a red gypsum landfill generated by the industrial extraction of titanium. The authors listed Streptomyces sp. isolated from that site as highly metal tolerant and exhibiting the greatest potential to act as plant growth promoting (PGP) rhizobacteria in restoration of tailings dumps. The following PGP traits were taken into consideration: indoleacetic acid (IAA) production, phosphate solubilization, and siderophore production. Chen and Liu [57] tested Pseudomonas sp. isolated from the heavy metal-contaminated reclamation area in Shanxi Province, China for their effectiveness in P solubilisation. Several Pseudomonas strains appeared to be effective in P solubilisation, both in laboratory and pot studies.

\section{Conclusions}

The study confirmed that the amendment of highly metal-contaminated waste with compost and phosphate or iron oxide mixtures helps to establish plant growth and improves soil parameters. It also stimulates the biological activity of soil and the presence of functionally important groups of bacteria-for example, those fixing nitrogen and solubilising phosphorus. Furthermore, the study showed the importance of plant-microbiome interactions in initiating biological processes in such extremely contaminated soils-processes that are crucial for resistance of the soil ecosystem constructed by phytostabilisation actions.

In the phytostabilisation of smelter waste piles, phosphorus deficiency might be a strong limiting factor, especially when the area is not fertilized regularly. Zinc and lead smelter waste is usually deficient in P. Therefore, using a P-rich soil amendment and applying bacteria with P-solubilisation capacities are crucial components of the phytostabilisation strategy.

Our research has revealed that combining soil amendments and inoculation with preselected bacterial strains might improve the effectiveness of assisted phytostabilisation. The interactive application of bacteria and soil amendments, in some cases, resulted in greater grass biomass and nutrient availability. Additionally, the selected metal solubility indicators were decreased in the amended soils when the bacterial strains were applied. Greater or faster biomass production can be translated into more dense plant coverage and greater plant residue input to soil development processes that subsequently would improve plant growth conditions. The interaction of soil amendments and the inoculants improves nutritional conditions in soil and likely stimulates plant resistance to stress conditions. Such aided phytostabilisation techniques, involving both soil amendments and the inoculation would be especially important in cases when one-action remediation is applied and regular fertilization of the site is not planned. This, however, needs confirmation by field studies.

Author Contributions: Conceptualization, S.S., G.S. and T.S.; methodology, S.S. and G.S.; validation, S.S., investigation, S.S., A.M.-G. and M.P.; resources, S.S. and G.S.; data curation, S.S.; writingoriginal draft preparation, S.S.; writing —-review and editing, G.S. and T.S.; visualization, S.S.; supervision, G.S.; project administration, S.S.; funding acquisition, S.S. All authors have read and agreed to the published version of the manuscript.

Funding: This research was funded by National Science Centre, Poland, the project 2015/17/N/ST10/ 03182 (The role of microorganisms in the colonisation of smelter wastelands by plants and their impact on bioavailability of trace elements).

Institutional Review Board Statement: Not applicable.

Informed Consent Statement: Not applicable.

Acknowledgments: The authors of this article kindly acknowledge Jarosław Grzadziel, Institute of Soil Science and Plant Cultivation-State Research Institute for preparing bacterial strains for identification and Emilia Grzęda Institute of Soil Science and Plant Cultivation-State Research Institute for assistance with the pot experiment and the microbiological analyzes.

Conflicts of Interest: The authors declare no conflict of interest. 


\section{References}

1. Williamson, A.; Johnson, M.S. Reclamation of metalliferous mine wastes. In Effect of Heavy Metal Pollution on Plants; Applied Sciences Publishing: London, UK, 1981; Volume 2, pp. 185-212.

2. Patrzalek, A.; Strzyszcz, Z. Field studies on revegetation of tailings. Arch. Environ. Prot. 1980, 3-4, 165-180. (In Polish)

3. Stuczyński, T.; Siebielec, G.; Daniels, W.; McCarty, G.; Chaney, R. Biological aspects of metal waste reclamation with biosolids. J. Environ. Qual. 2007, 36, 1154-1162. [CrossRef]

4. Alvarenga, P.; Gonçalves, A.P.; Fernandes, R.M.; de Varennes, A.; Duarte, E.; Cunha-Queda, A.C.; Vallini, G. Reclamation of a mine contaminated soil using biologically reactive organic matrices. Waste Manag. Res. 2009, 27, 101-111. [CrossRef]

5. Siebielec, S.; Siebielec, G.; Stuczynski, T.; Sugier, P.; Grzeda, E.; Grzadziel, J. Long term insight into biodiversity of a smelter wasteland reclaimed with biosolids and by-product lime. Sci. Total Environ. 2018, 636, 1048-1057. [CrossRef] [PubMed]

6. Siebielec, S.; Siebielec, G.; Sugier, P.; Wożniak, M.; Grzadziel, J.; Gałązka, A.; Stuczyński, T. Activity and diversity of microorganisms in root zone of plant species spontaneously inhabiting smelter waste piles. Molecules 2020, 25, 5638. [CrossRef] [PubMed]

7. Wu, G.; Kang, H.B.; Zhang, X.Y.; Shao, H.B.; Chu, L.Y.; Ruan, C.J. A critical review on the bio-removal of hazardous heavy metals from contaminated soils: Issues, progress, eco-environmental concerns and opportunities. J. Hazard. Mater. 2010, 174, 1-8. [CrossRef] [PubMed]

8. Becerra-Castro, C.; Prieto-Fernández, Á.; Kidd, P.S.; Weyens, N.; Rodríguez-Garrido, B.; Touceda-González, M.; Acea, M.J.; Vangronsveld, J. Improving performance of Cytisus striatus on substrates contaminated with hexachlorocyclohexane (HCH) isomers using bacterial inoculants: Developing a phytoremediation strategy. Plant Soil 2013, 362, 247-260. [CrossRef]

9. Glick, B.R. Using soil bacteria to facilitate phytoremediation. Biotechnol. Adv. 2010, 28, 367-374. [CrossRef]

10. Haslmayr, H.P.; Meißner, S.; Langella, F.; Baumgarten, A.; Geletneky, J. Establishing best practice for microbially aided phytoremediation. Environ. Sci. Pollut. Res. 2014, 21, 6765-6774. [CrossRef] [PubMed]

11. Weyens, N.; van der Lelie, D.; Taghavi, S.; Newman, L.; Vangronsveld, J. Exploiting plant-microbe partnerships to improve biomass production and remediation. Trends Biotechnol. 2009, 27, 591-598. [CrossRef]

12. Siebielec, S.; Siebielec, G.; Urbaniak, M.; Smreczak, B.; Grzęda, E.; Wyrwicka, A.; Kidd, P. Impact of rhizobacterial inoculants on plant growth and enzyme activities in soil treated with contaminated bottom sediments. Int. J. Phytoremediat. 2019, 21, 325-333. [CrossRef] [PubMed]

13. Sessitsch, A.; Kuffner, M.; Kidd, P.S.; Vangronsveld, J.; Wenzel, W.W.; Fallmann, K.; Puschenreiter, M. The role of plant-associated bacteria in the mobilization and phytoextraction of trace elements in contaminated soils. Soil Biol. Biochem. 2013, 60, 182-194. [CrossRef] [PubMed]

14. Kidd, P.S.; Álvarez-López, V.; Becerra-Castro, C.; Cabello-Conejo, M.; Prieto-Fernández, Á. Potential role of plant-associated bacteria in plant metal uptake and implications in phytotechnologies. In Phytoremediation; Elsevier Ltd.: Amsterdam, The Netherlands; Academic Press: Cambridge, MA, USA, 2017; pp. 87-126, ISBN 9780128028537.

15. Vurukonda, S.S.; Vardharajula, S.; Shrivastava, M.; SkZ, A. Enhancement of drought stress tolerance in crops by plant growth promoting rhizobacteria. Microbiol. Res. 2016, 184, 13-24. [CrossRef]

16. Balseiro-Romero, M.; Gkorezis, P.; Kidd, P.S.; Vangronsveld, J.; Monterroso, C. Enhanced degradation of diesel in the rhizosphere of Lupinus luteus after inoculation with diesel-degrading and PGP bacterial strains. J. Environ. Qual. 2016, 45, 924-932. [CrossRef]

17. Mergeay, M.; Nies, D.; Schlegel, H.G.; Gerits, J.; Charles, P.; Van Gijsegem, F. Alcaligenes eutrophus CH34 is a facultative chemolithotroph with plasmid-bound resistance to heavy metals. J. Bacteriol. 1985, 162, 328-334. [CrossRef]

18. Pikovskaya, R.I. Mobilization of phosphorus in soil in connection with the vital activity of some microbial species. Mikrobiologiya 1948, 17, 362-370.

19. Hettiarachchi, G.M.; Pierzynski, G.M.; Ransom, M.D. In situ stabilization of soil lead using phosphorus and manganese oxide. Environ. Sci. Technol. 2000, 34, 4614-4619. [CrossRef]

20. Bruemmer, G.W.; Gerth, J.; Tiller, K.G. Reaction kinetics of the adsorption and desorption of nickel, zinc, and cadmium by goethite. I. Adsorption and diffusion of metals. J. Soil Sci. 1988, 39, 37-52. [CrossRef]

21. Li, Y.-M.; Chaney, R.L.; Siebielec, G.; Kershner, B.A. Response of four turfgrass cultivars to limestone and biosolids compost amendment of a zinc and cadmium contaminated soil at Palmerton, PA. J. Environ. Qual. 2000, 29, 1440-1447. [CrossRef]

22. Siebielec, G.; Chaney, R.L. Testing amendments for remediation of military range contaminated soil. J. Environ. Manag. 2012, 108, 8-13. [CrossRef] [PubMed]

23. Yandigeri, M.S.; Meena, K.K.; Singh, D.; Malviya, N.; Singh, D.P.; Solanki, M.K.; Yadav, A.K.; Arora, D.K. Drought-tolerant endophytic actinobacteria promote growth of wheat (Triticum aestivum) under water stress conditions. Plant Growth Regul. 2012, 68, 411-420. [CrossRef]

24. Tabatabai, M.A. Soil Enzymes. In Methods of Soil Analysis. Part 2. Microbiological and Biochemical Properties; SSSA Book Series 5; SSSA: Madison, WI, USA, 1994; pp. 775-826.

25. Casida, L.E.; Klein, D.A.; Santoro, T. Soil dehydrogenase activity. Soil Sci. 1964, 98, 371-376. [CrossRef]

26. Tabatabai, M.A.; Bremner, J.M. Use of p-nitrophenylphosphate for assay of soil phosphatase activity. Soil Biol. Biochem. 1969, 1 , 301-307. [CrossRef]

27. Wallace, R.H.; Lochhead, A.G. Qualitative studies of soil microorganisms: IX. Amino acid requirements of rhizosphere bacteria. Can. J. Res. 1950, 28, 1-6. [CrossRef] 
28. Fenglerowa, W. Simple method for counting Azotobacter in soil samples. Acta Microbiol. Pol. 1965, 14, $203-206$.

29. Martin, J.P. Use of acid, rose bengal, and streptomycin in the plate method for estimating soil fungi. Soil Sci. 1950, 69, 215-232. [CrossRef]

30. Burns, R.G.; DeForest, J.L.; Marxsen, J.; Sinsabaugh, R.L.; Stromberger, M.E.; Wallenstein, M.D.; Weintraub, M.N.; Zoppini, A. Soil enzymes in a changing environment: Current knowledge and future directions. Soil Biol. Biochem. 2013, 58, 216-234. [CrossRef]

31. Tiemann, L.K.; Billings, S.A. Indirect effects of nitrogen amendments on organic substrate quality increase enzymatic activity driving decomposition in a mesic grassland. Ecosystems 2011, 14, 234-247. [CrossRef]

32. Moeskops, B.; Buchan, D.; Sleutel, S.; Herawaty, L.; Husen, E.; Saraswati, R.; Setyorini, D.; De Neve, S. Soil microbial communities and activities under intensive organic and conventional vegetable farming in West Java, Indonesia. Appl. Soil Ecol. 2010, 45, 112-120. [CrossRef]

33. Kaczyńska, G.; Borowik, A.; Wyszkowska, J. Soil dehydrogenases as an indicator of contamination of the environment with petroleum products. Water Air Soil Pollut. 2015, 226, 372. [CrossRef]

34. Nannipieri, P.; Grego, S.; Ceccanti, B. Ecological significance of the biological activity in soil. In Soil Biochemistry; Marcel Dekker: New York, NY, USA, 1990; Volume 6, pp. 293-355.

35. Khan, A.G. Role of soil microbes in the rhizospheres of plants growing on trace metal contaminated soils in phytoremediation. $J$. Trace Elem. Med. Biol. 2005, 18, 355-364. [CrossRef]

36. Kumari, S.; Chourasia, S.K.; Singh, U.; Kant, R. Azotobacter: Its role in sustainable agriculture. New Agric. $2017,28,485-492$.

37. Lenart, A. Occurrence, characteristics, and genetic diversity of Azotobacter chroococcum in various soils of southern Poland. Pol. J. Environ. Stud. 2012, 21, 415-424.

38. Billah, M.; Khan, M.; Bano, A.; Hassan, T.U.; Munir, A.; Gurmani, A.R. Phosphorus and phosphate solubilizing bacteria: Keys for sustainable agriculture. Geomicrobiol. J. 2019, 36, 904-916. [CrossRef]

39. Maharajan, T.; Ceasar, S.A.; Ajeesh Krishna, T.P.; Ramakrishnan, M.; Duraipandiyan, V.; Naif Abdulla, A.D.; Ignacimuthu, S. Utilization of molecular markers for improving the phosphorus efficiency in crop plants. Plant Breed. 2018, 137, 10-26. [CrossRef]

40. Walpola, B.C.; Yoon, M. Prospectus of phosphate solubilizing microorganisms and phosphorus availability in agricultural soils: A review. Afr. J. Microbiol. Res. 2012, 6, 6600-6605.

41. Kucey, R.M.N. Phosphate solubilizing bacteria and fungi in various cultivated and fungi in various cultivated and virgin Alberta soils. Can. J. Soil Sci. 1983, 63, 671-678. [CrossRef]

42. Acosta-Martinez, V.; Down, S.; Sun, Y.; Allen, V. Tag-encoded pyrosequencing analysis of bacterial diversity in a single soil type as affected by management and land use. Soil Biol. Biochem. 2008, 40, 2762-2770. [CrossRef]

43. Susilowati, L.; Syekhfani, E. Characterization of phosphate solubilizing bacteria isolated from Pb contaminated soils and their potential for dissolving tricalcium phosphate. J. Degrade. Min. Land Manag. 2014, 1, 57-62.

44. Zinati, G.M.; Li, Y.C.; Bryan, H.H. Utilization of compost increases organic carbon and its humin, humic and fulvic acid fractions in calcareous soil. Compost Sci. Util. 2001, 9, 156-162. [CrossRef]

45. Siebielec, G.; Smreczak, B.; Klimkowicz-Pawlas, A.; Maliszewska-Kordybach, B.; Terelak, H.; Koza, P.; Łysiak, M.; Gałazka, R.; Pecio, M.; Suszek, B.; et al. Monitoring of Soil Chemical Quality of Agricultural Land in Poland in 2010-2012; Biblioteka Monitoringu Środowiska: Warszawa, Poland, 2012. (In Polish)

46. Metson, G.S.; Bennett, E.M. Phosphorus cycling in Montreal's food and urban agriculture systems. PLoS ONE 2015, 10, e0120726. [CrossRef] [PubMed]

47. Mackay, J.E.; Cavagnaro, T.R.; Jakobsen, I.; Macdonald, L.M.; Grønlund, M.; Thomsen, T.P.; Müller-Stover, D.S. Evaluation of phosphorus in thermally converted sewage sludge: P pools and availability to wheat. Plant Soil 2017, 418, 307-317. [CrossRef]

48. Kumpiene, J.; Bert, V.; Dimitriou, I.; Eriksson, J.; Friesl-Hanl, W.; Galazka, R.; Herzig, R.; Janssen, J.; Kidd, P.; Menchj, M.; et al. Selecting chemical and ecotoxicological test batteries for risk assessment of trace element-contaminated soils (phyto)managed by gentle remediation options (GRO). Sci. Total. Environ. 2014, 496, 510-522. [CrossRef]

49. Prueß, A. Action values for mobile $\left(\mathrm{NH}_{4} \mathrm{NO}_{3}\right.$-extractable) trace elements in soils based on the German national standard DIN 19730. In Proceedings of the Third International Conference on Biogeochemistry of Trace Elements, Paris, France, $15-19$ May 1995.

50. Rodríguez-Llorente, I.D.; Gamane, D.; Lafuente, A.; Dary, M.; El Hamdaoui, A.; Delgadillo, J.; Doukkali, B.; Caviedes, M.A.; Pajuelo, E. Cadmium biosorption properties of the metal-resistant Ochrobactrum cytisi Azn6.2. Eng. Life Sci. 2010, 10, 49-56. [CrossRef]

51. Clemente, R.; Walker, D.J.; Pilar Bernal, M. Uptake of heavy metals and As by Brassica juncea grown in a contaminated soil in Aznalcollar (Spain): The effect of soil amendments. Environ. Pollut. 2005, 138, 46-58. [CrossRef] [PubMed]

52. Dary, M.; Chamber-Pérez, M.A.; Palomares, A.J.; Pajuelo, E. "In situ" phytostabilisation of heavy metal polluted soils using Lupinus luteus inoculated with metal resistant plant-growth promoting rhizobacteria. J. Hazard. Mater. 2010, 177, 323-330. [CrossRef] [PubMed]

53. Wang, Y.; Zheng, X.; He, X.; Lü, Q.; Qian, X.; Xiao, Q.; Lin, R. Effects of Pseudomonas TCd-1 on rice (Oryza sativa) cadmium uptake, rhizosphere soils enzyme activities and cadmium bioavailability under cadmium contamination. Ecotoxicol. Environ. Saf. 2021, 218, 112249. [CrossRef]

54. Praburaman, L.; Park, S.H.; Cho, M.; Lee, K.J.; Ko, J.A.; Han, S.S.; Lee, S.H.; Kamala-Kannan, S.; Oh, B.T. Significance of diazotrophic plant growth-promoting Herbaspirillum sp. GW103 on phytoextraction of Pb and Zn by Zea mays L. Environ. Sci. Pollut. Res. Int. 2017, 24, 3172-3180. [CrossRef] 
55. Jeyasundar, P.G.S.A.; Ali, A.; Azeem, M.; Li, Y.; Guo, D.; Sikdar, A.; Abdelrahman, H.; Kwon, E.; Antoniadis, V.; Mani, V.M.; et al. Green remediation of toxic metals contaminated mining soil using bacterial consortium and Brassica juncea. Environ. Pollut. 2021, 277, 116789. [CrossRef]

56. Zappelini, C.; Alvarez-Lopez, V.; Capelli, N.; Guyeux, C.; Chalot, M. Streptomyces dominate the soil under Betula trees that have naturally colonized a red gypsum landfill. Front. Microbiol. 2018, 9, 1772. [CrossRef]

57. Chen, Q.; Liu, S. Identification and characterization of the phosphate-solubilizing bacterium Pantoea sp. S32 in reclamation soil in Shanxi, China. Front. Microbiol. 2019, 10, 2171. [CrossRef] [PubMed] 